\title{
再生可能工ネルギーの大規模開発と その長距離輸送
}

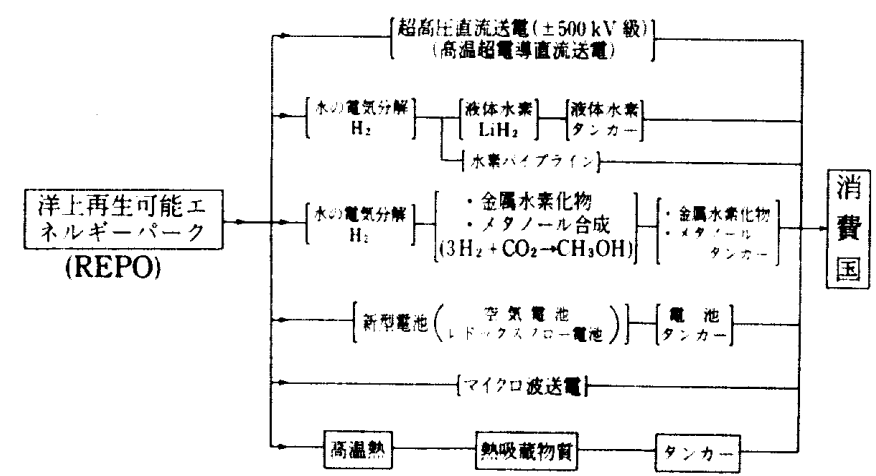

図 1 地球規模の長距離・高速・エネルギー輸送・貯蔵技術の例

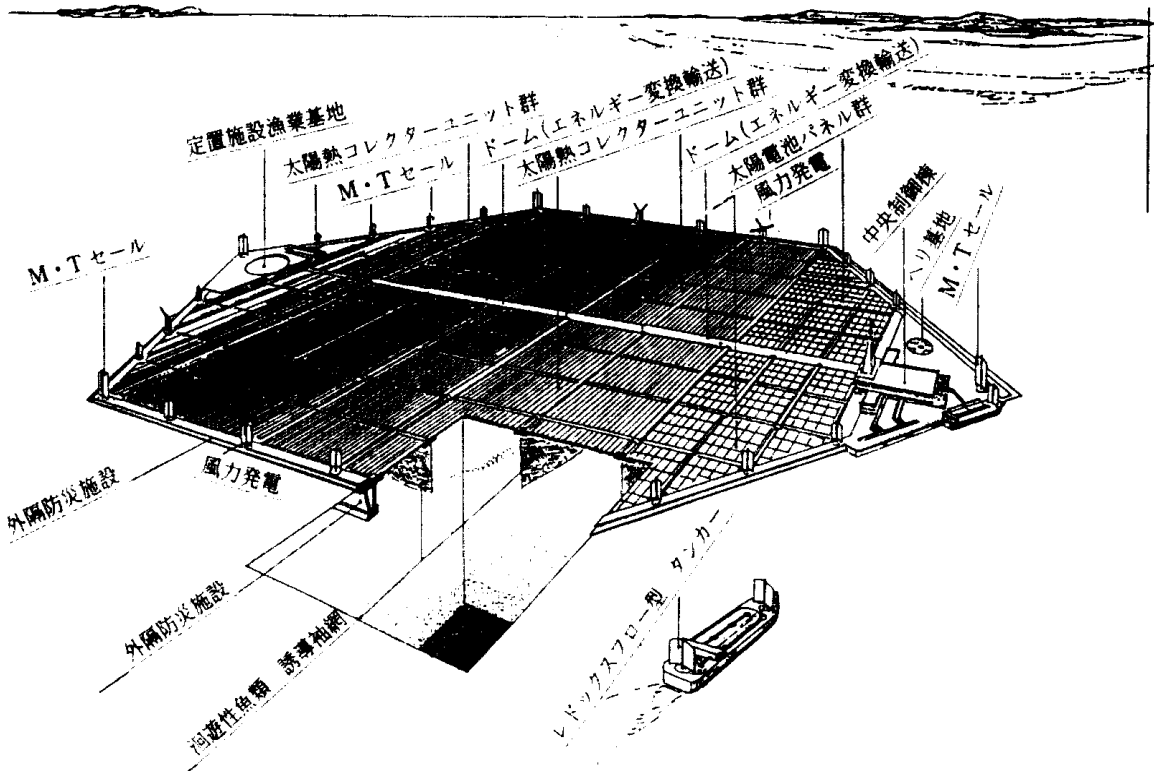

図 2 洋上再生可能エネルギーパーク構想〔Renewable Energy Park on Oceans (REPO) 構想]
地球環境問題の中で特に対応の 困難な課題は地球温暖化の防止で あり、これはすなわちエネルギー 問題でもある．温暖化防止策とし て短期的には省エネルギーが特に 重要であるが，中・長期的・抜本 的対策としては再生可能エネルギ 一（以下，再生エネと略）の大量 利用が必須であり，次の三つの計 画が検討されている。

\section{1. 世界の大規模水力の网発}

今後大規模水力開発の可能性の あるカナダ, シへリヤ, 中国, 南 米等にて大規模水力発電を行いそ の電力を図 1 に示すように液体水 素, または超高圧直流送電にて各
地に輸送する計画で，EC諸国や 日本で検討されている。

2、南方洋上（または硙溑）で の再生エネの大规模四発 図 2 に示すごとくいずれの国にも属さ ない人類共有の公海上（特に太陽 エネルギーの曹富な赤道付近）に 人類共有の財産である再生エネ変 換プラントを楎築し, $\mathrm{CO}_{2}$ を排 出しない太晹発電, 風力発電, 海 洋温度差発電, ソーラバイオ発電 などの複合発電を行い, その電力 を図 1 に示すような翰送方式で途 上国を始め世界各地に配送する。 またこのようなグローバルエネル ギーシステムの構築により地球規

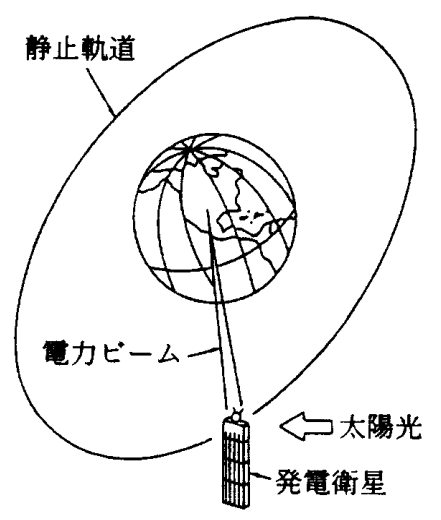

図 3 宇宙発婰の概念
模の時差を利用した経済的な電力 融通が可能となり，その恩恵は計り 知れないものがある.しかしこの ような計画の実現のためには，安 全な洋上浮揚構築物や図 1 のよう なエネルギー・電力の長距離輸送・ 貯藏技術の開発が必要である。

3. 宇宙での大規模太腹発 (宇宙発国) の閏発図 3 に示 すごとく地上約 $36000 \mathrm{~km}$ の赤道 上の静止軌道に太陽発電衛星を櫵 築し，その電力をマイクロ波にて 地上に伝送する計画である。1 1 工 ニットで 500 万 $\mathrm{kW}$ 程度の規模 を考えている。

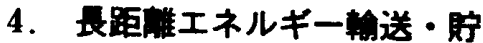
芸地球規模の長距離エネルギ 一貯蔵輸送方式として図 1 のよう なシステムが検討されている。す なわち電力として輸送する方式と しては超高圧直流送電（超電導直 流送電)，マイクロ波送電，新型 電池の輸送船による輸送方式が㭘 討されている。他の輸送媒体とし ては液体水素, メ夕ノール,アン モニア等を輸送船で輸送する方式 も考えられている。なお，輸送効 率は各方式とも大体 60～70\% 程 度と試算されている。

\section{文献}

（1）堀米，地球瓄境問題と再生可能工 ネルギー開発，太陽光発電システ ムシンポジウム, (1992-6), 1-59 $\sim 68$.

〔堀米 毒 東京農工大学〕 (原稿受付 1992 年 7 月 8 日) 